\title{
Asia: Challenges and Perspectives
}

DOI: $10.23932 / 2542-0240-2021-14-2-3$

\section{Political Culture of Transforming Countries: The Experience of China in the Past 40 Years since Reform and Opening Up}

\author{
Fei HAITING \\ DSc in History, Assistant Professor of Research Center of Chinese Politics, School \\ of Government \\ Peking University, 100871, Yi Heyuan St., no 5, Peking University, Haidian district, \\ Beijing, China \\ E-mail: feihaiting@outlook.com \\ ORCID: 0000-0001-5499-8863
}

\begin{abstract}
CITATION: Fei Haiting (2021) Political Culture of Transforming Countries: The Experience of China in the Past 40 Years since Reform and Opening Up. Outlines of Global Transformations: Politics, Economics, Law, vol. 14, no 2, pp. 48-65. DOI: 10.23932/2542-0240-2021-14-2-3
\end{abstract}

Received: 28.11.2020.

\begin{abstract}
Since the establishment of political culture analysis framework by Almond, it has become an important tool of political science and political analysis. The basic consensus on political culture is that a good political culture can promote political development. Many countries in transformation expect to shape their own civic culture as soon as possible to match their democratization process, but things often go against their wills. They are faced with a dilemma between traditional culture and civic culture at the very beginning of transformation. Besides, the development of political culture does not always present the simple path of traditional to modern type. Therefore, it is very necessary to reflect the principles of political culture development in combination with history and reality. From the view of Chinese scholars, political culture is neither only belief, feeling and attitude of individual, nor the ideology of a nation, but has multi-level con-
\end{abstract}

tent including ideology, value, psychology and action. This view combines the method of political culture analysis, the definition of Soviet culturology and the understanding of Chinese traditional culture. In transforming countries, the development of political culture is mainly manifested in the change and interaction of political subcultures. And at the same time, political subculture interacts with the change of social structure and political system. There are six main types of political subculture in transforming countries: political subculture of countryside and peasants, workers and migrant workers, private entrepreneurs, bureaucrats and officials, middle class and network. Through the analysis of these main types of political subculture in China after the reform and opening up, it can be concluded that political culture may present a complex path of development, and there may also be a variety of different development patterns and ideal forms. 
KEYWORDS: political culture, political transformation, subculture, Chinese politics

\section{The dillemma of political culture in transforming countries}

40 years ago, there was a unique phenomenon happened in China: the "culture fever". For no high threshold for the discussion of culture, and neither wealth nor power are needed for it, so soon, it spreads to every social class. It was like at a moment when everyone started talking about Chinese culture, and put everything they knew into this concept. It seems that everything in the world could be explained by culture - no matter they were originally political, economic, social, or even philosophical, historical and scientific problems. Moreover, events as big as international conflicts, change of political leaders, composition of the government, or as small and trivial as daily life habits, Qigong or Taiji, can all be ultimately attributed to cultural problems. In this simple way, Chinese people were expressing their reflection on history, understanding of reality, and expectation for the future. At the same time, people were using this way, through the discussion of culture, to express their concerns and different views on politics in this land.

If we look at the "culture fever" from a historical perspective, then everything will be explainable. 40 years ago, in 1980s, 2 major events took place in political history of China - the end of the "cultural revolution" and the beginning of "reform and opening up". The former implied that many traditional ideas, words, symbols and habits are no longer "rotted" things which are harmful to development and need to be destroyed. Meanwhile, the later indicated that every member of this political community has a great expectation for change. In their thoughts, "change" did not only refer to some concrete policies, but also discussion about series of basic and fundamental problems: the direction of devel- opment, the path of modernization and so on. In fact, "Reform" and "opening up" complemented each other. Without "reform", it was very difficult for China to truly open up to the world and accept experiences of development from foreign countries; without "opening up", it is also difficult for China to fully understand the advantages and disadvantages of existing different modernization paths, let alone learn from others and reform its own system.

When the "culture fever" began in the 1980s, discussants involved were faced with a dilemma. On the one hand, China has a long history of thousands of years and has left many valuable institutional heritages. But on the other hand, China must admit the fact that western countries have stronger state capacity. Although some of these countries have not developed for a long time, but their political regime and institutions were proven to have significant advantages in international competition. If Chinese people in 1980s acknowledge the superiority of their own tradition, it would be very difficult for them to deny the legitimacy of the traditional political regime and institutions, which will inevitable delay the process of modernization. If they admitted the advantages of foreign experiences, it would be very difficult for them to accept the process of culture transplantation and admit that their culture needs to be "improved". This is why countries in transformation are very easily caught up in the debate between extreme xenophobia and extreme exclusionism. Tendency in debate about culture was not only shown in support of one side, but usually also in rejection of another. Therefore, it was difficult for traditional culture supporters to accept foreign experience, and also hard for modern culture supporters to fully accept traditional heritages.

As a result, every potential supporter for modernization of China in 1980s has to answer a series of questions about transformation of culture. Some of the most critical questions are as follows. First of all, into 
what form should political culture in China transform? Secondly, does the transformation of political culture have the same path, such as from tradition to modern, from parochial to participant? Thirdly, will the political culture develop and transform in the same model? Does it develop from middle class to the whole society or transform in process of conflicts between state and society?

\section{The definition of political culture in China}

Talking about transformation of political culture, the first question will be: what is political culture? Obviously, political culture as an academic term is very different from the definition of culture in the "culture fever". However, it should be noted that there are also some differences between Chinese scholars' understanding and classical definition of political culture.

It is undeniable that the political and cultural research methods, which were widely accepted and used in China in the 1980s, are inherited from the political culture framework established by Almond [ $\mathrm{Al}$ mond 1956, pp. 391-409] and Verba [Almond, Verba 1963] in the 1950s and 1960s, followed by Pye [Pye, Verba 1965; Pye 1972, pp. 285-296] and others in the 1960s and 1970s, and revived by Inglehart [Inglehart 1977] and others in the 1980s. The basic assumption of this approach is: firstly, the operation of a political system is based on the subjective and common tendency of a group of people; secondly, the subjective tendency of this group can be measured and inferred by individual attitude.

But in fact, the use of definition "political culture" in China is not a simple transplantation of the methods of political culture analysis built by Almond [Wang Huning 1987].

In China, the concept of political culture integrates at least three aspects: Al- mond's method of political culture analysis, Chinese traditional political thought and Soviet culturology.

In Soviet time, cultural problems were not considered as simple traditions, habits, emotions, attitudes or psychological feelings. They were regarded as subjective aspects of political life or spiritual products of human activities. The basic content of political culture is to take ideology as the core, political knowledge as the main content, and political activities (as well as political system and political institutions) as the reflections. Like professor Irkhin pointed out: basic elements of culture include language and words, value system, symbol and cultural artifact [Irkhin 2017].

In Chinese tradition, politics and culture are mutually reinforcing. Politics, political thoughts, and political culture are closely intertwined. On the one hand, politics maintained the absolute control and domination of political culture; on the other hand, culture also made up for the lack of political domination and control ability in ancient China. This determines that in ancient China cultural issues are not just personal attitudes, emotions, or moral cultivation, but cover the whole political system and life.

In short, in the field of political culture, Chinese scholars have widely accepted the intermediate definition of "political culture", which includes political thoughts and ideology, political values, political psychology and political behavior. Qi Heng made a figurative metaphor, that is, the political culture is like a sphere, in which the political thought and ideology are at the core, the political psychology and behavior are at the shell, and the political value lies between them [Qi Heng 1988, pp. 29-39].

Chinese scholars have gradually reached some basic consensus in understanding the definition of political culture.

Firstly, neither individual's political psychology, emotion, and attitude, nor 
the political ideology at the national level should be the main or only content of political culture. In fact, people's preferences and tendencies should be examined at the social and social group level, because different subculture types are constantly changing, and individual psychology is greatly affected by the subculture groups to which they belong. Furthermore, it should be realized that there is a certain distance between design and actual effect of political ideology on political culture, not all the political thoughts and requests of ideology could be practiced in real life.

Secondly, the development of political culture does not always present the oneway logic of traditional to modern culture, or parochial to participant culture. The cultural characteristics of different countries and regions have different influences on its path of development. It may not only go upward but also could return or even go downward, and may derive other forms in the process of development. The "western world" does not have a unified political and cultural model, therefore, path of development of political culture in transforming countries should be considered beyond the western standard.

The process of China's political modernization has lasted more than a hundred years and its journey is rough. Over the past century, China's political and social structure has undergone earth shaking changes. Many social groups were split and disappeared, At the same time, new social groups were emerging. This leads to a fundamental change in structure of China's political subcultures, resulting in the high complexity of contemporary structure of Chinese political subcultures. Therefore, every specific political subculture type should also be analyzed and evaluated in addition to the overall observation and investigation to fully understand the contemporary political culture in China.

In summary, from the perspective of political subculture types, there are main- ly 6 of them, including political subculture of countryside and peasants, workers and migrant workers, private entrepreneurs, bureaucrats and officials, middle class and network culture.

\section{Political subculture of countryside and peasants}

Since China's modernization process was initiated by the political and intellectual elites gathered in the cities, the vast number of grassroots rural peasants have become the most complete carriers of traditional political culture. In the rural areas of traditional China, the three main forces are state, familial and social power [Luo Zhenglin 2008, pp. 108-113]. After 1949, the concrete embodiment of state power is the party branch. The familial power is made up of some extended families. Social power mainly refers to various mechanisms of villagers' autonomy, like the village committee. Many different forces imply the complexity of authority in the countryside.

In the history before the Qing Dynasty, peasants did not directly participate in politics, but interacted with the grass-roots political institutions of the state through agents and autonomous organizations in a collective way. Due to the need to rely on this system to maintain social order, for a long time the village has also replaced the rule of law with etiquette, emphasizing morality rather than rules.

This was often thought, that the grassroots politics in China is the administrative integration of county government and countrysides, which means counties and towns belong to the state, while in villages peasants lived their real lives. However, Professor Skinner has pointed out, there was in fact another level under the level of counties and towns - the Xiangchang (乡 场, the market) [Skinner 1993]. The most basic political units in traditional China 
were not natural villages, but market communities, that is, the market in the center or an area, which includes several villages. But this system of market was separate from the administrative hierarchy of the state. In recent researches, as according to Sun Ming, the system of market was not separated from administrative hierarchy, but was an administrative unit in itself. It consisted of Tuanlian (团练, militia, including their training and support) as a financial mechanism, Yiliang (议粮, discussing the price of silver in the collection of land tax) as a consultation procedure, Gongju (公局, squire discussed public affairs such as charity and public order) as a representative institution [Sun Ming 2020, pp. 36-52]. This unit absorbed all kinds of formal and informal governance mechanisms, and took "the Market" as the pivot, so that grass-roots politics could be smoothly functioning.

After the founding of new China, party branches and village committees began to be set up in rural areas. The village committee is still the autonomous organization of villagers, and the party branch is the representative of the state power. The role of natural village in grass-roots politics began to strengthen. In this way, peasants need to participate in political life directly. Chinese peasants began to realize their rights and obligations in voting to deciding on the use of collective property, deciding on major issues of collective life, generating authority by election. At the same time, the traditional family began to disintegrate. Peasants began to take the family or even the individual as the unit of political activities. However, the awakening of rights awareness does not mean respect for rules. Leninist Party has brought the awakening of authority and right consciousness, but it is difficult to shape the concept of rule of law in rural areas in only 30 years.

In fact, from experience of China, political participation at grass-roots level was gradually transforming from elite politics to mass democracy. That is, from the gentry and squire played the role of representative, developing to the direct participation of peasants. In this process, guidance from the state is necessary. State needs to actively guide them, to shape, to accept and to respect rules built by themselves, rather than directly impose institutions, rules or laws on them. Because such rules are not understood by them as being beneficial to themselves, but to the state. If so, there will inevitably appeared many actions or movements, trying to bypass the rules and seeking their own interest, instead of caring the public welfare.

Peasants' political participation is difficult to be identified as extensive and organized. In some places, there is even a phenomenon of profiteering petition: taking advantage of the government's attention to stability and order, they deliberately obtain policy preference or seek benefits through "making noises" - making trouble to solve troubles. Obviously, this is a kind of anti-establishment political participation. If this kind of informal participation activity continues for a certain time, it may actually be solidified into a specific political culture. This is obviously harmful to the construction of a benign interaction between the state and society.

This is also the experience that the development of rural political culture in China suggests: the development speed of right consciousness and participation habit should be relatively synchronous. If the awareness of rights is not sufficiently inspired, people will not have enough motivation to reach consensus and take collective action by means of assembly or association, then the channels or platforms of participations will be in vain. However, if the channels and platforms of participation are not improved in time, people who have awakened to the consciousness of rights will take participation outside the rules to express their demands. As a result, 
these actions will lead to mobilization, resistance, even conflict into habits and culture, which is very harmful to the shaping of a civic culture.

\section{Political subculture of workers and migrant workers}

Before the reform and opening up, China implemented the planned economy. This leads to a unique vertical relationship in China's political structure: large stateowned enterprises and their affiliated enterprises. Such large-scale state-owned enterprises have not only a large number of subsidiary industries, but also a series of subsidiary institutions from kindergartens to hospitals. The political culture of workers belonging to this system will not be formed around the province, city, town or village simply according to the level of national governance, but mainly depends on the overall political culture of the enterprise. From employment to retirement, workers gather in a certain department for a long time, so that the socialization process of them is mainly completed inside the enterprise. The political participation of the workers is realized through the two structures of the party branch and the administrative management of the enterprise, where the administrative and production management are highly unified. Due to the lofty status, workers have been an enviable job for several decades. This often leaves the children of workers tend to stay in the same system with their parents. When two or three generations of workers are engaged in the same kind of work, their family culture is in fact highly integrated with the political culture of the enterprise where they belong to. The stability of the factory work and the long-term life of the factory make the political culture of enterprises, especially those large-scale state-owned enterprises in steel, energy, petrochemical, transportation, machin- ery manufacturing, become a very special type: huge, stable, not easy to change. However, once new trends and ideas appear, they will soon spread throughout the whole system.

After the reform and opening up, although there are still many state-owned enterprises, the number of private enterprises and foreign-invested enterprises began to increase significantly due to the promotion of mixed ownership economy. The political culture of these enterprises is quite different from that of traditional state-owned ones. First of all, these kinds of enterprises are not aimed at controlling social resources and production process, but making profits. Therefore, there is no need to set up a large number of subsidiary organs affiliated to enterprise or ultimately build up a whole system. Secondly, the mobility of workers in such new enterprises is far greater than that in traditional state-owned ones. In addition, the management mode of such enterprises is totally different from that of traditional state-owned enterprises, which neither integrates administration and production management, nor undertakes the function of political participation channels and platforms. Therefore, the relationship between workers' socialization and political participation and enterprises is much looser.

Furthermore, the problem of migrant workers seems to be more serious. In the traditional state-owned enterprises, even if the first generation of workers are still born in peasants, through a long time or even several generations of socialization, the political subculture of them has changed greatly. However, for the current workers, especially for those in private or foreign-invested enterprises, it is difficult to completely change the original culture in rural areas and form a stable political subculture type in the absence of stable socialization process and channels or platforms for political participation. The migrant 
workers, they belong to the rural population, so the institutionalized mechanism of participation still belongs to the countryside; however, in most of their time they are working in cities and towns, so the demand for political participation occurs in their new residences. Therefore, theses migrant workers fall into the dilemma of unemployment of mechanism of institutional participation and the fact of non-institutionalized participation [Wei Linzhen, Zhong Hai 2007, pp. 55-60]. Some scholars pointed out that although hundreds of millions of peasants entered the city, their political subculture did not advance along the traditional-modern one-way route, but presented three possibilities: civic culture, subjective culture and even mob culture [Xu Zengyang 2004, pp. 61-70]. If the integration process of urban and rural areas is gradual and smooth, then migrant workers who can obtain participation chances can develop a civic culture. But in contrast, workers who are more mobile but whose working time and working places are still located in local enterprises will still show subjective culture. While workers, who are far away from the countryside and have great demand for participation and expression but lack channels, may develop a special type of mob culture.

\section{Political subculture of private entrepreneurs}

The political culture of private entrepreneurs mainly refers to the owners of private enterprises as a whole, who have some similar values, goals and understanding in politics. The key elements of the political subculture of private entrepreneurs lie in their relationship with the government, including how to communicate with the government and how to reach a consensus to take collective actions. This determines their subjective perception of the political system as a whole.
In the relationship between the state and the market, a long-term unanswered question is: why are entrepreneurs still willing to invest, when there is no property right protection. Zhou Lian has pointed out, that between local governments of China exists "Promotion Tournament" [Zhou Lian 2007, pp. 36-50]. According to his research, there is a fierce competition among local governments in China in economic development. In order to attract investment and encourage the development of private enterprises, local governments will not infringe upon them capriciously or excessively. However, the form of this subculture highly depends on the attitude of local governments to private enterprises, but the strategies, paths and possibilities of economic development of each province or city are very different. Hence even if this theory eliminates some of concerns, subculture of private entrepreneurs is still uncertain an unstable.

After the reform and opening up, China's private enterprises have a rapid development. According to the classification of Kelle Tsai, there are 5 main types of private entrepreneurs [Tsai 2005, pp. 1130-1158]: marginalized private entrepreneurs, disguised private entrepreneurs, dependent $\&$ red private entrepreneurs, incorporated private entrepreneurs and rationalizing private entrepreneurs. Marginalized PE means they develop their own enterprises independently. Disguised PE means they are private enterprises, but actually operates as collective or state-owned businesses. Dependent \& red PE means they actually function as symbiotic clientelism. Incorporated PE means they have strong ties to the state. And Rationalizing PE means they support legal-rational institutional environment.

The different types actually result from the different development modes of private enterprises in China. Professor Heberer and Schubert divided this development path of private enterprises also into 5 
models [Heberer, Schubert 2020]: Pearl River Delta model, Southern Jiangsu model, Jinjiang model, Wenzhou model, and Enshi model. Pearl River Delta model based on foreign investment, and local governments provide sound environment, they are appeared as local state entrepreneurialism. Southern Jiangsu model refer to privatization of former township enterprises. Their owners have tight connections to the local state, and their managers are actually former township managers, they appeared as local state developmentalism. Jinjiang model reflects the rise of native $\mathrm{PE}$, they are not party members, but have close state-enterprise connections based on kinship and localism. Private enterprises in Wenzhou model were originally low-tech or labor-intensive export production, initiated by native PE, they have informal finance networks and like laissez-faire economy. In contrast, they have strong translocal and transnational networks, and now they are pushing for industrial restructuring and upgrading. Enshi model based on rural private sector development, have few industrial enterprises, but have much more tourism and agricultural processing, $\mathrm{PE}$ in this model strongly dependent on local government. Local governments of these places strive to attract external investment. They are in fact late-coming development.

From their development model, it is not difficult to see that the political subculture of private entrepreneurs in a certain region as a whole largely depends on the connection of their profit model to the local government. Professor Heberer and Schubert pointed out that the relationship between the government and enterprises will be affected by following factors: whether the local government participates directly in economic activities, whether the local government formulates a clear and strong economic strategy, or whether there is a systematic mechanism to encourage enterprise innovation
[Heberer, Schubert 2020]. Similarly, private entrepreneurs will also use series of methods to exert influence on policies and local government. Common methods include impact on private sector policies, on legislation, organizing lobbying activities, bargaining with governments, arranging discourses with government, and organizing collective action. Which one of those methods is effective will affect which part of the political process these private entrepreneurs prefer to participate in, and thus affect their political subculture from the perspective of political efficacy.

Economy and tax are the foundation of modern state, and are also one of the most important driving forces of development. Since the reform and opening up, China has realized that the market is not just an appendage of the state. It is necessary to respect the autonomy of the market and the general rules of market operation. Although the state and government play a guiding role in economic development, they need to keep a roughly balanced relationship with the market. However, there is a lack of institutional resources for reference in China's political history. China is still in the stage of "crossing the river by feeling the stones".

It can be seen from above, that private enterprises with different development models have diverse degrees of attachment to the local government. So that their ability and willingness to take collective action or political participation will also be variant. This will result in many different forms of political subculture among private entrepreneurs, ranging all the way from highly organized and active political participation to highly dependent on informal rules and indifference in politics. Ultimately, political subculture of private entrepreneurs as a whole, still depends on the rule of law, especially in relationship between state and market. In this process, although under the pressure of performance competition, local govern- 
ments still need to exercise self-restraint, communicate with business owners equally and effectively, so as to build a legal and orderly political subculture of private entrepreneurs.

\section{Political subculture of bureaucrats and officials}

Before the modernization, China was basically a typical agricultural state. The political structure of the agricultural state and the interaction between the state and society can be directly simplified as the interactive relationship between officials and peasants. Therefore, the political subculture among bureaucrat and officials, in addition to the political subculture of rural areas and peasants, is the most important in an agricultural state. Since Qin and Han Dynasty, the legitimacy of Confucianism was established. This made political rule and rulers in ancient China have a systematic, comprehensive, profound and detailed theoretical support, and at the same time, it made the Confucianism have the authoritative status and the possibility of wide spread. Confucianism not only determines the principles of politics at the national level, but also goes deep into daily life and becomes the moral code of common people. This determines that in ancient China, cultural issues are not just personal attitudes, emotions or moral cultivation, but the whole national political system and political life.

For the political culture of bureaucrat and officials, this feature is more obvious. In minds of bureaucrat and officials in ancient China, any decision-making activity and stance are not purely technical issues, but highly related to their moral standards. Since the Song Dynasty, a typical feature of political conflicts is that every group of bureaucrat tend to regard themselves as “Junzi”(君子, a man of moral integrity) and denounce their opponents as "Xiaor- en” (小人, villains). The original intention of this kind of political culture is to control the behavior motivation of political elites to a certain extent. But its negative effect is that the moral judgment is also connected with the result of decision-making. Since effective decisions come from classic teachings and moral cultivation, bad decisions are also associated with lower moral standards. This makes the evaluation criteria of bureaucrat, officials and even policies lack of objectivity and neutrality. The inevitable result of this feature is the spread of clientelism. A middle and low-level bureaucrat or officials cannot have enough voice to defend his moral level and legitimacy of his decision-making, so he needs to be attached to an elite group. This is also a common feature of feudal bureaucracy.

After the founding of PRC, China's modernization process began to accelerate, and the political structure of agricultural state began to change fundamentally. The state no longer needs political culture to make up for the lack of ruling capacity. The state extends its capacity to the countryside. At the same time, the state has completed its control ability of social wealth through the industrialization process and state-owned enterprises. However, as for the bureaucratic groups, the change of political structure has not thoroughly changed its political subculture.

In addition, as Csanadi has pointed out, in a regime like party-state, dependent system widely exists both in state and party hierarchy [Csanadi 2006]. This makes it difficult to remove the clientelism in the bureaucratic group.

From the perspective of moral judgment, although the state no longer needs to rely on ideology and culture to make up for the lack of institutional capacity, but because its legitimacy comes from Marxism Leninism, it also has high moral requirements for bureaucrats. In the political theory of Leninism, communist party is the vanguard of the working class, so it 
also attaches great importance to the ideology and political education. This makes the decision-making process of bureaucrats and officials also highly related to the standard of their political consciousness.

For instance, the newest criteria for the CPC to select cares at present is "De, Neng, Qin, Ji, Lian” (德、能、勤、绩、廉: ideological morality, working competence, diligence and working attitude, performance, honest and integrity) [Regulations on the Work of Selecting and Appointing Leading Party and Government Cadres 2014]. This criteria guarantees the quality of political elites. And this maybe the reason that professor Bell concludes Chinese politics as "Meritocracy" [Bell 2015], which means qualified elite could be selected through this mechanism to promote the political development. But problem still exists: any regime or political system is clearly aware of importance of quality of political elite, and hopes to pick them out to act as agents of governance. But not all regimes or systems are able to fulfil this task. Obviously, in the experience of the CPC, exists some effective methods. However, these "effective methods" do not only refer to the selection of outstanding people, but also the mechanism to cultivate relatively inexperienced novices into excellent bureaucrats, and promote their effective experience nationwide, while not making them too big to fall, which will inevitably lead to corruption and abuse of power. This not just includes selection, but also training, learning, communication and institutional constraints, especially intra-party democracy. As professor Wang Changjiang criticized, the problem of democratic politics cannot be solved by meritocracy, and the difficulties of democratic politics will also perplex the meritocracy. Hence meritocracy could hardly live without a developed democratic politics, and hard to replace or challenge the democracy [Wang Changjiang 2018].

An important plan in the reform and opening up is the improvement of this par- ty-state regime, that is, to achieve the goal of separating politics from administration, so as to solve the above problems. However, this reform is not as fast and smooth as economic reform.

\section{Political subculture of middle class}

The middle class has always been regarded as the core part of civil society, for it is not only the active advocate of democratization, but also the key factor for "making democracy work" [Putnam, Leonardi, Nanetti 1994]. But in China's political practice, it is not difficult to find that the political subculture of the middle class is not simple and highly consistent, but extremely complex. In other words, the middle class is not actually all staunch supporters of democratization. Political subculture of the middle class in transforming countries depends on whether they are "in" or "out" of the political system.

The logic of the middle class's support for democratization lies in the hypothesis that economic growth brings about the growth of personal income, and the growth of personal income will make benefited group have higher requirements for rights and rules to protect their property, so they will have a stronger willingness to participate in politics. Since members of this group are usually highly educated, and distributed in some important government and social sectors, their attitude will also have a significant impact on attitude of government. When taking collective action in the form of association or assembly, they can force the government to promote democratic reform and rebalance the relationship between the state and society. But there are actually two problems in this logic: first, the economic growth brought about by market-oriented reform is not necessarily equal to the increase of personal income. In many cases, results of 
reform are more likely to be intercepted by elite groups, resulting in the widening gap between the rich and the poor. Secondly, the socialization process and education of the middle class are also closely related to their political structure when they are teenagers, in which the content of education is very different in developed countries. Thirdly, the middle class in transforming countries does not all come from the "market" and private sectors, but has a complex background.

In a party-state regime similar to the Soviet Union, there are actually only middle-income groups, but no middle class. As a concept, the middle class can be established, only based on the premise that the concept of property rights exists, that is, private property is sacrosanct. But in the party-state regime, public sector usually played an absolute main role in all economic activities. The relationship between the property of middle-income group, their social status and political influence are significantly different from that of other regimes. In a standard civil society, in order to maintain their social status and life, middle-income groups need to defend the property rights, and protect their property from illegal taxation, that is, not to be absorbed unlimitedly by the state. However, in the society of party-state, the most important thing for middle-income groups to maintain their status is to protect their political status first. Due to the tight binding of political role, social status and economic income, once the political role is lost, all kinds of income channels and social insurance will be simultaneously deprived. Therefore, except for some special cases (like intellectual or nationalist associations), the middle-income groups in party-states will hardly support any kind of radical democratic reforms.

For party-states in the process of political transformation, the middle-class is usually not all from the private sectors, but can be divided into two categories: the mid- dle class within the system and the middle class outside the system. Sun Long believes that whether the middle class belongs to "the system" determines differences in their political attitudes [Sun Long 2010, pp. 94-100], which is embodied in their cognition of the matching degree of their own political and economic status. In many cases of political transformation, the state decides which areas of the national economy should continue to be controlled by state-owned enterprises, as well as the scale of foreign investment and the development of private enterprises in the process of market-oriented reform. These factors jointly determine the distribution proportion of the middle-class within and outside the system. In conclusion, the middle class can indeed serve as a stable pillar of social order, but whether its political subculture can guide the whole society to the civic culture still depends on the complicated interaction between state, society and market in the process of transformation.

\section{Political subculture of network}

In the process of political transformation, there is also a kind of political subculture worth mentioning - the political culture on internet. In the Internet age, the content, form and carrier of political culture itself have changed a lot. Decades ago, many people were optimistic about the political culture of this age. Their basic logic is: Internet is naturally open and widely connected. Therefore, the spread of information will be more convenient than any other era in the history of mankind. Thus, the Internet is bound to promote democratization. However, in fact, although in some countries and regions, the Internet has indeed extended the scope and strength of social movements, and the social network has indeed played an important role in many electoral activities and democratization waves, the po- 
litical culture on Internet has not caused fundamental changes as people expected. On the contrary, in some cases, it not only aggravates the tearing of society, but also intensifies the polarization of subcultural groups, which makes the contradictions between social groups more acute. This is mainly because of two misunderstandings about the political culture of Internet.

First of all, the politics of the Internet age is simply understood as the participation from the side of common people. This misunderstanding seriously underestimates the development speed of digital governance. In the era of Internet, it is easy and convenient for individuals to communicate and contact with others and to express their opinions and attitudes, for the society to express diverse views, and to a certain extent reach a basic consensus. But it is easier and more convenient for states to enhance their capabilities through the Internet. The Internet makes the communication between state and society more convenient and easier to reach consensus in the field of public policy, and makes many plans possible that could not have been achieved before. For example, the health code policy during the epidemic of COVID-19 has enabled the national capacity to really reach the community rather than stay at the urban level. In short, the political culture of the Internet does not only belong to individuals, but also to society and the state.

Secondly, the development process of political culture is simply understood as the transformation from traditional to internet style. Just as what has been proved before, the development of political culture does not appear as a one-way traditional-modern model, but has multiple possible paths. In the Internet age, the process of decentralization that was originally expected did not happen. Optimistic forecasters seriously underestimate the resilience of traditional culture. People choose to only believe what they want to believe, and that's why the Oxford Dictionary named "post-truth" as the word of the year for 2016, and that is why we also call the Internet age the post-truth era. Besides, the opening feature of Internet does not bring unlimited spread of information, but the formation of many "information cocoons". People were trapped in filter bubbles, built by platforms, could only read and hear the same voice like their own. Furthermore, many researches have already proven, that the process of information spread in the Internet is not controlled by "the people", but continues to be held and concentrates in the hands of "netocracy" [Kochetkov 2011, pp. 8-20].

In essence, what the Internet has erased is only the gap between individuals and collective action. Jin Taijun and Li Juan believe that network politics is actually the extension of real politics in cyberspace [Jin Taijun, Li Juan 2014, pp. 52-58]. The existence of the Internet eliminates the restriction conditions for the rise of individual consciousness into collective action, thus catalyzing the outbreak of network groups, and thus promoting the construction of a benign interactive relationship between the government and citizens. It is easier for individuals to act collectively within a subcultural group. However, the relationship between the state and society, and the relationship between the state and various subcultural groups has not been obviously impacted by the Internet. In conclusion, Internet, like middle-class, has its own complex attributes. In the political process, they usually play the role as a booster, more than the role as an engine.

\section{Conclusion}

In China, the discussion about political culture began after the reform and opening up. Professor Yu Keping had concluded the transformation of political transformation of China since then as the 
dual variation of modernization and globalization [Yu Keping 2006]. It has three main tasks at the same time: reflecting on the "cultural revolution", resisting the impact of foreign thoughts, and reestablishing national identity. This makes this it takes the grand task of using the concept of political culture to promote China's political modernization from the very beginning. People were debating and establishing political culture, aiming at exploring and choosing the path of modernization for China. In short, the discussion political culture in China is not only about questions of "what" and "why", but also have a clear purpose to find the answer of "how". Therefore, the reality and experience of China's development of political culture can reflect not only the reality of China, but also some common rules of other states in transformation.

From China's experience, we can see that there are some distinct differences between the political culture development of transforming countries with the standard model of western countries, even with the model of "new democracies".

First of all, the political culture development of transforming countries is not a oneway model. It will not necessarily develop along the traditional-modern path, nor will it necessarily develop along the path of parochial-subject-participant. Different forms will be built according to the political system, social structure, economic development, and the interaction mechanism between the state and society. In places where the pace of institutionalization cannot match the demand of political participation, the political culture will not evolve, but will degenerate or even deteriorate.

Secondly, the ideal type of political culture in transforming countries is not necessarily a textbook civic culture, especially not necessarily the model of oppression on state by society. State played important and strong role for a very long time in history of many trans- forming countries. So that the development of political culture by means of social resistance may make the society pay a high price in the struggle with the state. The best way to achieve goals may not be to force the state by means of conflicts and social movements, but more likely to achieve the coordinated governance of the state and society. Therefore, the mode of political culture development in transforming countries does not necessarily emphasize the unlimited development of individual, but more likely to focus on the balance and harmony among the state, market and society.

Therefore, the key to the development of political culture in transforming countries may still lie in state and government. This is not only a realistic way of development, but also a relatively low-cost development path. Yet it's worth noting that, crucial role of state and government in political culture development does not mean that the state can only actively and initiatively guide or shape a certain political culture. China's experience has proved that it is also possible for the state to passively shape the political culture through sharing some of the powers and functions originally belonging to the state with society and market, so that people can participate more in the processes of motion, discussion, decision-making, feedback and supervision. The political culture formed in such interaction may be the really ideal and suitable type for the transforming countries.

\section{References}

Almond G. (1956) Comparative Political Systems. Journal of Politics, vol. 18, no 3, pp. 391-409. DOI: 10.2307/2127255

Almond G., Verba S. (1963) The Civic Culture: Political Attitudes and Democracy in Five Nations, Princeton University Press. 
Bell D. (2015) The China Model: Political Meritocracy and the Limits of Democra$c y$, Princeton University Press.

Csanadi M. (2006) Self-consuming Evolutions: A Model on the Structure, Self-reproduction, Self-destruction and Transformation of Party-state Systems Tested in Romania, Hungary and China, Budapest: Akadémiai Kiadó.

Heberer T., Schubert G. (2020) Weapons of the Rich: Strategic Action of Private Entrepreneurs in Contemporary China, World Scientific Publishing Company. DOI: $10.1177 / 0097700418808755$

Inglehart R. (1977) The Silent Revolution, Princeton Press University.

Inglehart R. (1988) The Renaissance of Political Culture. American Political Science Review, vol. 82, no 4, pp. 1203-1230. DOI: $10.2307 / 1961756$

Inglehart R. (1990) Culture Shift in Advanced Industrial Societies, Princeton Press University.

Inglehart R. (1997) Modernization and Post-modernization: Cultural, Economic and Political Changes in Societies, Princeton Press University.

Irkhin V. (2017) Political Culture, Part 1: West and Russia, Moscow: Yurajt (in Russian).

Jin Taijun, Li Juan (2014) Interaction between Virtual and Reality: The Social Function Mechanism of Network Political Culture. Social Science Research, no 3, pp. 52-58 (in Chinese). DOI: $10.3969 /$ j.issn.1000-4769.2014.03.007

Kochetkov P. (2011) Power and Elite in Global Informational Society. POLIS, no 5, pp. 8-20. Available at: https://www.politstudies.ru/article/4456, accessed 31.01.2021 (in Russian).

Luo Zhenglin (2008) The Main Context of Political Culture Changes in China's Rural Areas - State, Familial and Social Power. Probe, no 6, pp. 108-113 (in Chinese). DOI: 10.16501/j.cnki.50-1019/d.2008.06.029

Putnam R., Leonardi R., Nanetti R. (1994) Making Democracy Work: Civic
Traditions in Modern Italy, Princeton University Press.

Pye L. (1972) Culture and Political Science: Problems in the Evaluation of the Concept of Political Culture. Social Science Quarterly, vol. 53, no 2, pp. 285-296. Available at: https://www.jstor.org/stable/42858958, accessed 31.01.2021.

Pye L. (1991) Political Culture Revisited. Political Psychology, vol. 12, no 3, pp. 487-508. DOI: 10.2307/3791758

Pye L., Verba S. (1965) Political Culture and Political Development, Princeton University Press.

Qi Heng (1988) An Analysis of the Structure of Political Culture. Cass Journal of Political Science, no 1, pp. 29-39 (in Chinese).

Regulations on the Work of Selecting and Appointing Leading Party and Government Cadres (2014). People.com.cn, January 16, 2014. Available at: http://renshi.people.com.cn/n/2014/0116/c13961724132485.html, accessed 31.01.2021 (in Chinese).

Skinner G. (1993) Marketing and Social Structure in Rural China. The Journal of Asian Studies, vol. 24, no 1, pp. 3-43. DOI: $10.2307 / 2050412$

Sun Long (2010) The Political Attitude of the Urban Middle Class: An Investigation and Analysis Based on House Property Owners Group in Beijing. Journal of Jiangsu School of Administration, no 6, pp. 94-100 (in Chinese). DOI: 10.3969/j.issn.1009-8860.2010.06.015

Sun Ming (2020) Markets and the Operation Mechanism of Tuanlian Practice in Sichuan in the Late Qing Dynasty. Research on Modern History, no 3, pp. 36-52. Available at: http://www.cnki.com.cn/Article/CJFDTotal-JDSY202003004.htm, accessed 31.01.2021 (in Chinese).

Tsai K. (2005) Capitalists without a Class: Political Diversity among Private Entrepreneurs in China. Comparative Political Studies, vol. 39, pp. 1130-1158. DOI: 10.1177/0010414005277021 
Wang Changjiang (2018) Review on "Meritocracy". PKU Political Science Review, no 2, pp. 3-24. Available at: http://www.cnki.com.cn/Article/CJFDTotal-BDZP201802001.htm, accessed 31.01.2021 (in Chinese).

Wang Huning (1987) Comparative Political Analysis, Shanghai People's Press (in Chinese).

Wei Linzhen, Zhong Hai (2007) The Evolution of Migrant Workers' Political Culture and the Construction of Harmonious Society. Journal of Xian Jiaotong University, no 3, pp. 55-60 (in Chinese). DOI: 10.3969/j.issn.1008-245X.2007.03.011

Xu Zengyang (2004) A Political Sociological Analysis of "The Tide of Mi- grant Workers". Cass Journal of Political Science, no 1, pp. 61-70. Available at: http://qikan.cqvip.com/Qikan/Article/ Detail?id=9598879, accessed 31.01.2021 (in Chinese).

Yu Keping (2006) The Logic of Chinese Cultural Development under the Dual Variation of Modernization and Globalization. Academic Monthly, no 4, pp. 14-24 (in Chinese).

Zhou Lian (2007) Research on the Promotion Tournament Model of Local Chinese Officials. Economic Studies, no 7, pp. 36-50 (in Chinese). 


\title{
Политическая культура \\ в трансформационных странах: опыт Китая за 40 лет после реформы и открытости
}

\author{
Фэй ХАЙТИН \\ кандидат исторических наук, доцент Центра исследования китайской политики, \\ Школа Государственного Управления \\ Пекинский Университет, 100871, Yi Heyuan St., no 5, Peking University, Haidian \\ district, Beijing, China \\ E-mail: feihaiting@outlook.com \\ ORCID: 0000-0001-5499-8863
}

\section{ЦИТИРОВАНИЕ: Fei Haiting (2021) Political Culture of Transforming Countries: The Experience of China in the Past 40 Years since Reform and Opening Up. Outlines of Global Transformations: Politics, Economics, Law, vol. 14, no 2, pp. 48-65. DOI: 10.23932/2542-0240-2021-14-2-3}

Статья поступила в редакцию 28.11.2020.

\begin{abstract}
АННОТАЦИЯ. $C$ тех пор, как теория «политической культуры» была создана для научного анализа Г. Алмондом, она стала важным инструментом политических и политологических исследовании. В основе теории тежит консенсус в отночении того, что хорошая политическая культура может способствовать политическому развитию. Многие странь, находящиеся на трансбормационном этапе, стремятся как можно скорее сбормировать свою гражданскую культуру в соответствии с процессом демократизации, но зачастую это идет вразрез с их волей. В самом начале переходного периода они столкнулись с дилеммой выбора традиционной и гражданской культурь. Кроме того, развитие политической культуры не всегда сопровождается традиционным подходом к
\end{abstract}

современности. Поэтому необходимо размышление о принципе развития политической культуры с учетом истории и реальности. По мнению китайских ученых, политическая культура это не только нравственность, эмоиия и отношение тичности, не только идеология страны - в нее включается многоуровневое содержание: идеология, иенность, психология и поведение человека. Эта точка зрения сочетается с теорией политической культуры, определением советской культурологии и пониманием традиционной культурь Китая. В трансбормачионных странах развитие политической культуры проявляется главным образом в изменении и взаимодействии разных политических субкультур. В то же время политическая субкультура взаимодействует с изменениями в соии- 
альной структуре и политической системе. Политическая субкультура в трансформационных странах характеризуется шестью основными видами: политической субкультурой сельских и крестьянских районов, политической субкультурой традиционных городских рабочих и рабочих из числа мигрантов из сельской местности, политической субкультурой частных предпринимателей, политической субкультурой бюрократии и чиновников, политической субкультурой среднего класса и политической субкультурой в Интернете. Анализ основных видов политической субкультуры в Китае после реформы позволяет сделать вывод о том, что политическая культура может представлять собой сложный путь развития, а также различные идеаль и модели.

КЛЮЧЕВЫЕ СЛОВА: политическая культура, политическая трансбормация, политическая субкультура, китайские политики

\section{Список литературы}

Ирхин Ю.В. (2017) Политическая Культура, Часть 1: Запад и Россия. М.: Юрайт.

Кочетков А.П. (2011) Власть и элиты в глобальном информационном обществе // ПОЛИС. № 5. С. 8-20 // https://www.politstudies.ru/article/4456, дата обращения 31.01.2021.

Almond G. (1956) Comparative Political Systems // Journal of Politics, vol. 18, no 3, pp. 391-409. DOI: 10.2307/2127255

Almond G., Verba S. (1963) The Civic Culture: Political Attitudes and Democracy in Five Nations, Princeton University Press.

Bell D. (2015) The China Model: Political Meritocracy and the Limits of Democracy, Princeton University Press.
Csanadi M. (2006) Self-consuming Evolutions: A Model on the Structure, Self-reproduction, Self-destruction and Transformation of Party-state Systems Tested in Romania, Hungary and China, Budapest: Akadémiai Kiadó.

Heberer T., Schubert G. (2020) Weapons of the Rich: Strategic Action of Private Entrepreneurs in Contemporary China, World Scientific Publishing Company. DOI: $10.1177 / 0097700418808755$

Inglehart R. (1977) The Silent Revolution, Princeton Press University.

Inglehart R. (1988) The Renaissance of Political Culture // American Political Science Review, vol. 82, no 4, pp. 1203-1230. DOI: $10.2307 / 1961756$

Inglehart R. (1990) Culture Shift in Advanced Industrial Societies, Princeton Press University.

Inglehart R. (1997) Modernization and Post-modernization: Cultural, Economic and Political Changes in Societies, Princeton Press University.

Jin Taijun, Li Juan (2014) Interaction between Virtual and Reality: The Social Function Mechanism of Network Political Culture // Social Science Research, no 3, pp. 52-58 (на китайском). DOI: $10.3969 /$ j.issn.1000-4769.2014.03.007

Luo Zhenglin (2008) The Main Context of Political Culture Changes in China's Rural Areas - State, Familial and Social Power // Probe, no 6,pp. 108-113 (на китайском). DOI: 10.16501/j.cnki.50-1019/d.2008.06.029

Putnam R., Leonardi R., Nanetti R. (1994) Making Democracy Work: Civic Traditions in Modern Italy, Princeton University Press.

Pye L. (1972) Culture and Political Science: Problems in the Evaluation of the Concept of Political Culture // Social Science Quarterly, vol. 53, no 2, pp. 285-296 // https://www.jstor.org/stable/42858958, дата обращения 31.01.2021.

Pye L. (1991) Political Culture Revisited // Political Psychology, vol. 12, no 3, pp. 487-508. DOI: $10.2307 / 3791758$ 
Pye L., Verba S. (1965) Political Culture and Political Development, Princeton University Press.

Qi Heng (1988) An Analysis of the Structure of Political Culture // Cass Journal of Political Science, no 1, pp. 29-39 (на китайском).

Regulations on the Work of Selecting and Appointing Leading Party and Government Cadres (2014) // People.com.cn, January 16, 2014 // http://renshi.people. com.cn/n/2014/0116/c139617-24132485. html, дата обращения 31.01.2021 (на китайском).

Skinner G. (1993) Marketing and Social Structure in Rural China // The Journal of Asian Studies, vol. 24, no 1, pp. 3-43. DOI: $10.2307 / 2050412$

Sun Long (2010) The Political Attitude of the Urban Middle Class: An Investigation and Analysis Based on House Property Owners Group in Beijing // Journal of Jiangsu School of Administration, no 6, pp. 94-100 (на китайском). DOI: $10.3969 /$ j.issn.1009-8860.2010.06.015

Sun Ming (2020) Markets and the Operation Mechanism of Tuanlian Practice in Sichuan in the Late Qing Dynasty // Research on Modern History, no 3, pp. 36-52 // http://www.cnki.com.cn/Article/CJFDTotal-JDSY202003004.htm, дата обращения 31.01.2021 (на китайском).

Tsai K. (2005) Capitalists without a Class: Political Diversity among Private
Entrepreneurs in China // Comparative Political Studies, vol. 39, pp. 1130-1158. DOI: $10.1177 / 0010414005277021$

Wang Changjiang (2018) Review on "Meritocracy" // PKU Political Science Review, no 2,pp.3-24//http://www.cnki.com. cn/Article/CJFDTotal-BDZP201802001. $\mathrm{htm}$, дата обращения 31.01.2021 (на китайском).

Wang Huning (1987) Comparative Political Analysis, Shanghai People's Press (на китайском).

Wei Linzhen, Zhong Hai (2007) The Evolution of Migrant Workers' Political Culture and the Construction of Harmonious Society // Journal of Xi'an Jiaotong University, no 3, pp. 55-60 (на китайском). DOI: 10.3969/j.issn.1008-245X.2007.03.011

Xu Zengyang (2004) A Political Sociological Analysis of "The Tide of Migrant Workers" // Cass Journal of Political Science, no 1, pp. 61-70 // http://qikan.cqvip.com/ Qikan/Article/Detail?id=9598879, дата обращения 31.01.2021 (на китайском).

Yu Keping (2006) The Logic of Chinese Cultural Development under the Dual Variation of Modernization and Globalization // Academic Monthly, no 4, pp. 1424 (на китайском).

Zhou Lian (2007) Research on the Promotion Tournament Model of Local Chinese Officials // Economic Studies, no 7, pp. 36-50 (на китайском). 